УДК 821.161.1

\title{
ОСОБЕННОСТИ МИРОМОДЕЛИРОВАНИЯ В ПОЭМЕ В.И. МАЙКОВА «ЕЛИСЕЙ, ИЛИ РАЗДРАЖЕННЫЙ ВАКХ»
}

\author{
Безрукова Марина Викторовна \\ аспирант \\ Северный (Арктический) федеральный \\ университет им. М.В. Ломоносова
}

Аннотация: В работе представлена оригинальная оценка мотивов поступка литературного героя в произведении В.И. Майкова «Елисей, или Раздражённый Вакх». Принципиальная «внесистемность» - главная особенность майковского героя в отличие от европейских литературных предшественников. По мнению автора работы, сознательная установка на изображение маргинального героя и маргинального мира определяет во многом новизну комической поэмы В.И. Майкова и свидетельствует об изменениях художественной картины мира. (Исследование выполнено при финансовой поддержке РФФИ в рамках научного проекта № 20-312-90035).

Ключевые слова: Русская литература, В.И. Майков, картина мира, мотив поступка, маргинальный герой.

\section{FEATURES OF WORLD MODELING IN V.I. MAYKOV'S POEM «ELISEY, OR BACCHUS ENRAGED»}

\section{Bezrukova Marina Viktorovna}

\begin{abstract}
This work presents the original estimation of the motives of the action of the literary character of V.I. Maykov's work "Elisey, or Bacchus Enraged". The principal "non-system" is the main feature of Maykovsky's character, in contrast to his European literary predecessors. According to the work's author, namely conscious orientation to representation of a marginal personality and marginal world largely defines the novelty of V.I. Maykov's comic poem and indicates changes in the artistic picture of the world. (The reported study was funded by RFBR, project number 20-312-90035).
\end{abstract}




\section{ВСЕРОССИЙСКИЙ ФИЛОЛОГИЧЕСКИЙ ФОРУМ}

Key words: Russian literature, V.I. Maykov, picture of the world, an action's motive, a marginal character.

Поэма В.И. Майкова «Елисей, или Раздраженный Вакх» традиционно оказывается в центре внимания исследователей русской литературы 60-70 гг. XVIII века, как один из оригинальных образцов травестийной поэзии. Однако создавая свою поэму, В.И. Майков, несомненно, отходит от традиций европейского понимания жанров бурлеска и травестии, во всяком случае, от тех, которые обозначили себя во французской литературе XVIII века, здесь подобного рода поэмы строились либо как «пародии по принципу травестированного снижения высокого предмета героической эпопеи»; либо в форме «использования атрибутов и стиля высокой героической эпопеи применительно к тривиальной будничной ситуации» [1, с. 75].

Одна из этих жанровых разновидностей бурлескной поэмы представлена в творчестве Поля Скаррона, который средством достижения комического эффекта сделал неувязку высокого сюжета с низким стилем. С точки зрения классицистических творческих установок это был низкий вид искусства, поскольку он компрометировал высокое содержание героического эпоса. Поэтому Н. Буало предложил другой вид бурлеска, противоположный Скаррону по своим установкам. Буало взял низкую тему - мелкую бытовую ссору между церковными служками, и воспел ее высоким стилем эпопеи с соблюдением всех формальных правил этого жанра в поэме «Налой». Так сложился второй вид бурлеска, более предпочтительный, для французского классицизма, поскольку он извлекал комический эффект из несоответствия низкого бытового сюжета высокому стилю его изложения.

Поэмы в духе Скаррона не вписывались в систему классицистических жанров, поэтому по мере утверждения этого направления были отодвинуты на второй план. Жанр поэмы в духе Буало культивировался классицистами, поскольку соответствовал их представлениям о высоком и низком в искусстве. Однако в практике русского классицизма между двумя этими стилистическими установками большой разницы не видели. Поэма В.И. Майкова является убедительным подтверждением этому. В тексте поэмы легко и непринужденно соединяются обе эти установки. И причина этого остается непроясненной до сих пор.

Первоначально поэма была задумана как пародия на перевод В.П. Петрова, «карманного» одописца Екатерины II. Стилистическая 


\section{ВСЕРОССИЙСКИЙ ФИЛОЛОГИЧЕСКИЙ ФОРУМ}

концепция перевода выполненного Петровым, не удовлетворила писателей сумароковской школы, они выступили с резкой критикой. Наиболее значительным выпадом в ходе этой полемики и стала публикация поэмы Майкова. Весь сюжет «Елисея» сохранил следы первоначального пародийного замысла: создавая комическое отображение художественной манеры Петрова, Майков пользуется такими сложившимися приемами, как комическая стилизация и пародийное цитирование.

Н.И. Новиков в своем «Опыте исторического словаря о российских писателях» высоко оценил бурлескную поэму Василия Майкова: «Сочинил он прекрасную поему <..> Елисей, или раздраженный Вакх во вкусе Скарроновом, похваляемую <..> тем паче, что она первая у нас такая правильная шутливая издана поема» [2, с. 134]. Однако стоит заметить, что «Елисей» противоречит правилам как Буало, так и Скаррона. Точнее говоря, являет собой смешение тех и иных правил. Аналогичен новиковскому отзыв и М.М. Хераскова, который в статье «Рассуждение о российском стихотворстве» (1772) отметил, что в «Елисее» Майков «явил нам Скаррона своими чертами находчивыми, живыми, занимательными, и своими забавными выдумками» [3, с. 287-294.]

Лишь несколько десятилетий спустя А.А. Шаховской в предисловии к собственной ирои-комической поэме «Расхищенные шубы», ставит под сомнение вывод о «правильности» «Елисея»: «Содержание поэмы, взятое из само простонародных происшествий, и буйственные действия его героев не позволяют причесть сие острое и забавное творение к роду ирои-комических поэм, необходимо требующих благопристойной шутливости» [4, с. 87]. Вслед за Шаховским, Н. Остолопов отдает предпочтение «Шубам», согласно тем же представлениям о правилах, в соответствии с которыми должны писаться поэмы подобного рода [5, с. 188]. И П.А. Вяземский видел недостаток «Елисея» в «отсутствии комической веселости, то есть души подобных творений» [6, с. 135-136].

Даже В.Г. Белинский отнесся к Майкову неодобрительно: «прославился двумя так называемыми «комическими» поэмами, но мы, кроме площадных красот и веселости дурного тона, ничего в них не могли найти» [7, с. 78]. А А.А. Бестужев-Марлинский, характеризуя писателей екатерининской эпохи в своей статье «Взгляд на старую и новую словесность в России», так отозвался о В.И. Майкове: «В шутовском роде (burlesque) известны у нас Майков и 


\section{ВСЕРОССИЙСКИЙ ФИЛОЛОГИЧЕСКИЙ ФОРУМ}

Осипов. Первый оскорбил образованный вкус своею поэмою «Елисей» <...>» [8, c. 375-393].

Если не учитывать слов защиты, высказанных в адрес поэмы Майкова со стороны А.С. Пушкина, Н.М. Карамзина, то придется констатировать, что в первой половине XIX столетия она воспринималась преимущественно в негативном оценочном поле, что резко контрастирует с оценками современников В.И. Майкова, на которых поэма, очевидно, произвела благоприятное впечатление.

Оценивая этот факт, одни исследователи [9] считают, что поэма, наполненная вульгарной лексикой, имела цель эпатировать, ошеломить благопристойного читателя. А, например, Г.А. Гуковский, утверждает, что «дворянские вкусы в XVIII веке не были чопорны, и салонная изысканность еще не была свойственна даже русским щеголям эпохи Майкова» [10, с. 71].

Современные исследования, посвященные анализу поэмы В.И. Майкова, стремятся представить ее в контексте процессов аналогичных тем, которые породили подобного рода поэмы в западноевропейской литературе XVIIXVIII веков. Например, Л.А. Казакова [11] определяет ее как продукт эволюции жанра комической поэмы, обусловленной взаимодействием двух ее проявлений в русской литературе эпохи («салонной» и «низовой» поэмы). При этом майковский текст относится к образцам низовой комической поэмы. А то обстоятельство, что он соединяет в себе признаки совершенно разных явлений французской литературной традиции XVII столетия, уходит на второй план.

Несколько ранее Л.А. Казаковой, предложил свое видение природы художественного мира майковского «Елисея» Н.И. Николаев [12]. Он со ссылкой на фундаментальные идеи М.М. Бахтина, увидел здесь черты «карнавального мира». Концептуальное понимание художественного мира В.И. Майкова, основанного на противопоставлении миропорядка героической поэмы и празднично-карнавальной жизни изложено в ряде его работ [13].

Такой подход, основанный на весьма убедительном анализе своеобразия художественного времени в поэме В.И. Майкова, несомненно, роднит поэму с произведениями П. Скаррона. Но наблюдения эти требуют некоторого уточнения. Цикличность художественного времени русской поэмы, обусловленная сменой праздничных и будничных его фаз, предполагает и цикличность поступков героя. Но майковский Елисей не меняется. На время «великого поста» он, как отмечает сам Н.И. Николаев [14], лишь «прячется» в 
Калинкином доме, но по своей природе, по мотивам своих поступков остается неизменным. Подчиненность праздничным циклам социальной жизни, в которую вовлечен Елисей, не распространяется на самого героя. Его мотивация лежит, очевидно, вне этой цикличности.

Принципиально важным для характеристики художественного мира поэмы В.И. Майкова стало соединение в его произведении стилистических установок Н. Буало и П. Скаррона. То, что было принципиально недопустимым во французской литературе XVII века, дало совершенно новые и неожиданные результаты в русской поэзии XVIII столетия.

Стилистическая игра, изменение полюсов «высокого» и «низкого», предложенная французскими авторами, по существу не меняла самой системы, противопоставления полярных явлений. «Высокое» могло представляться «низким» и наоборот, они менялись местами, но при этом не разрушалась граница, разделяющая их.

Литературный герой поэмы В.И. Майкова как представитель «мстительного» Вакха на Земле должен восприниматься как часть «высокого» мира стилистически сниженного, и в этом смысле автор поэмы следует установкам П. Скаррона. Однако одновременно, вступающий в поединки «кулачный боец» Елисей предстает перед нами «низким» персонажем, обыгранным в высоком стилистическом ключе. Все это, несомненно, вносит хаос в систему ценностных ориентиров по линии «высокое/низкое», разрушает смысловые границы, разделяющие их.

Главная особенность майковского героя - его принципиальная «внесистемность» в отличие от европейских литературных предшественников. Автор помещает его в различные жизненные сферы, каждая из которых определена своим социальным укладом: мир зимогорских крестьян и семейного быта, мир городских ямщиков, мир «темничной юдоли», мир обитателей Калинкиного дома, мир откупщиков, мир богов-олимпийцев. Каждый из них базируется на некой системе ценностных смысловых установок, а все персонажи демонстрируют приверженность этим разным смыслам и ценностям, кроме Елисея, который демонстративно и с удивительным постоянством все их отвергает. Он последовательно «внесистемен», неуправляем даже богами-олимпийцами.

Все эти перечисленные выше социальные страты представлены в поэме В.И. Майкова в ироническом или откровенно сатирическом ключе. И этот фон обеспечивает симпатии к главному герою со стороны читателя. 


\section{ВСЕРОССИЙСКИЙ ФИЛОЛОГИЧЕСКИЙ ФОРУМ}

Художественные акценты, расставленные в поэме В.И. Майкова, открывают совершенно новые возможности литературного моделирования социального мира. Его герой принадлежит не социальному низу, как полагают многие комментаторы этого текста, он в своих поступках движим мотивами, не укладывающимися ни в какие известные (принятые) нормы социального поведения. Это герой, живущий за пределами, за чертой социальных устоев, т.е. маргинальный герой. Появление персонажа такого типа самим фактом своего существования оттеняет понятие социальной нормы, поскольку маргинальное в социальном мире и есть то, что находится за чертой нормального.

В русской литературе до В.И. Майкова (например, в творческом наследии А.П. Сумарокова) описание и осмысление социального мира осуществлялось в процессе его сопоставления с вечным и незыблемым нравственным идеалом. Сакральный смысл этого идеала и отклонение от него в реальной жизни создавали то ценностно-смысловое напряжение, с помощью которого формировалась художественная модель социального мироустройства.

Социальный порядок, которому привержены персонажи поэмы Майкова, лишен сакральных атрибутов. Это всего лишь принятая, условная социальная норма, оттененная мотивами поступка маргинального героя. По наблюдениям современных исследователей изменение мотивов поступка литературного героя как историко-литературного явления свидетельствует об изменениях художественной картины мира [15].

«Маргинальное» в социальном мире и «социальная норма» становятся принципиально новыми инструментами миромоделирования в поэме В.И. Майкова.

\section{Список литературы}

1. Ирои-комическая поэма / Ред. и примеч. Б.В.Томашевского; вступ. ст. В.А.Десницкого. Л.: Изд-во писателей в Ленинграде, 1933. 773 с. (Библиотека поэта; Большая серия).

2. Новиков Н.И. Опыт исторического словаря о российских писателях. СПб., 1772. Репринт: М., 1987. С. 264. 


\section{ВСЕРОССИЙСКИЙ ФИЛОЛОГИЧЕСКИЙ ФОРУМ}

3. Рассуждение о российском стихотворстве. Неизвестная статья М.М.Хераскова. Публикация П.Н.Беркова // Литературное наследство. Т. 910. М.: Журнально-газетное объединение, 1933. 521 с.

4. Шаховской А.А. Комедии, стихотворения [Текст] / Вступ. статья [c. 5-72], подготовка текста и примеч. А.А. Гозенпуда. - Ленинград : Сов. писатель, 1961. - 828 с.

5. Словарь древней и новой поэзии, составленный Николаем Остолоповым, действительным и почетным членом разных Ученых обществ: [В 3 ч.] Ч. 1. СПб.: Типография Императорской Рос. Академии. 1821. 492 с.

6. Вяземский П.А. Известие о жизни и стихотворениях Ивана Ивановича Дмитриева // Вяземский П.А. Полное собрание сочинений. Т. I. СПб.: Тип. М.М.Стасюлевича, 1878. 356 с.

7. Белинский В.Г. Собрание сочинений: В 9 т. Т. 1: Статьи, рецензии и заметки, 1834-1836; Дмитрий Калинин / Ред. кол.: Н.К.Гей [и др.]. М.: Худож. лит., 1976.736 с.

8. Бестужев-Марлинский А.А. Взгляд на старую и новую словесность в России // Бестужев-Марлинский А.А. Сочинения: В 2 т. Т. 2: Повести; Рассказы; Очерки; Стихотворения; Статьи; Письма / Сост., подгот. текста, коммент. В.Ш. Сулешова. М.: Худож. лит., 1981. 592 с.

9. Западов А.В. Творчество В.И. Майкова // Майков В.И. Избранные произведения. М.; Л.: Сов. писатель, 1966. 504 с.

10. Гуковский Г.А. Поэты XVIII века // Поэты XVIII века: Херасков М.,Майков В., Богданович И. и др. Л.: Сов. писатель, 1936. 429 с.

11. Казакова Л.А. Жанр комической поэмы в русской литературе второй половины XVIII - начала XIX вв.: генезис, эволюция, поэтика / Л.А. Казакова. - Псков: Издатель-ство ПГПУ, 2009. - 448 с.

12. Николаев Н.И. Жанр бурлеска в творчестве русских писателей 60 -х70-х годов XVIII века // О жанрово-стилевом своеобразии (по страницам литературы): сб. науч. трудов. - Ташкент: ТашГУ, 1985. - С. 85-95.

13. Николаев Н.И. Русская литературная травестия: Вторая половина XVIII - первая половина XIX века. Архангельск: Поморский гос. ун-т им. М.В.Ломоносова, 2000. 120 с.

14. Николаев Н.И. Смеховое начало в поэме В.И. Майкова «Елисей, или Раздраженный Вакх» // Филологические науки. 1986. № 5. С. 77-79. 
15. Николаев Н.И., Швецова Т.В. Русский литературный герой 30-40хгодов XIX века и проблема поступка / Н.И. Николаев, Т.В. Швецова // Фундаментальные исследования. - 2014. - №3-1. - С. 201-204. 